Małgorzata SIWICKA

(Lublin, KUL)

\title{
STAROŚĆ - SZANSA CZY ZAGROŻENIE DLA ROZWOJU MORALNEGO CZLOWIEKA W OCENIE STOIKÓW
}

Starość w świecie antycznym Grecji i Rzymu, wbrew obiegowym opiniom, nie cieszyła się szczególnym szacunkiem i poważaniem. Oczywistym wyjątkiem w świecie greckim była oczywiście Sparta, znana ze swej estymy dla podeszłego wieku. Jej ustrój polityczny opierał się na geruzji - radzie starców, postanowieniom której musieli podporządkowywać się nawet spartańscy królowie. Należy jednak pamiętać o tym, że zasiadali w niej mężowie z wysokich, arystokratycznych rodów spartańskich, którzy w okresie swej młodości wykazywali się innymi cnotami, bardziej przydatnymi w bezpośredniej walce z nieprzyjacielem niż doświadczenie życiowe i mądrość, jaką przynosi podeszły wiek. Szacunek jaki okazywano w Sparcie ludziom starszym nie zależał tylko i wyłącznie od liczby przeżytych lat ${ }^{1}$.

Generalnie jednak postrzegano starość jako wiek trudny i uciążliwy, zarówno dla samego człowieka dotkniętego starością, jak i dla jego bliskich, rodziny i przyjaciół. „Gorsza od śmierci, która nadaje ludzkiej doli znamię wielkości, wydaje się zgrzybiałość, w której karleją bohaterowie. Szczęśliwy Aleksander, który nie zaznał zmarszczek! Zdobywca zawdzięcza sławę swej młodości, jak jego wzór - boski Achilles; a jakiż żałosny byłby widok zwycięzcy Persów zwyciężonego przez reumatyzm! [...] W całej historii Grecji, począwszy od najdawniejszych czasów [...] od spowitych mrokiem epok, w których zaczynała powstawać mitologia, starość była zawsze uważana za przekleństwo"2. W pieśniach Homera Nestor cieszy się co prawda poważaniem, ale dzieje się tak nie tyle ze względu na jego podeszły wiek, ile na heroiczne czyny. Pomimo bardzo zaawansowanego wieku staje on do walki i dowodzi swymi oddziałami, gdyż ,nieszczęsnej starości poddawać się nie chciał bohater”3. Innym starcom również okazywany jest szacunek dlatego, że

${ }^{1}$ Por. W. Jaeger, Paideia, thum. M. Plezia - H. Bednarek, Warszawa 2001, 146 i 159, a także N.G.L. Hammond, Dzieje Grecji, tłum. A. Świderkówna, Warszawa 1994, 144 i 147.

${ }^{2}$ G. Minois, Historia starości. Od antyku do renesansu, tłum. K. Marczewska, Warszawa Gdańsk 1995, 53.

${ }^{3}$ Homerus, Ilias I 260; X 76, ed. P. Mazon: Homére, Iliade, Les Belles Lettres, Paris 1937, 13 i 86. 
w młodości byli herosami, a dopiero później ze względu na ich doświadczenie i mądrość. Pojawiają się sytuacje, gdy tych samych starców karci się dość obcesowo lub wytyka im gadulstwo a nawet grozi, zwłaszcza gdy ich słowa nie przypadną do gustu słuchaczom ${ }^{4}$.

Równie smętny obraz starości przedstawia Hezjod, który czyni starość córką Nocy. Jej rodzeństwem są Przeznaczenie, Szyderstwo, Strapienie, Ułuda i Zwada ${ }^{5}$. Podobnie posępną wizję rozsnuwa poeta Mimnermos ${ }^{6}$, a także pojawia się ona w niektórych dziełach trzech wielkich tragików greckich: Ajschylosa, Sofoklesa i Eurypidesa ${ }^{7}$.

Oczywiście postawy te ulegały przekształceniom i zmianom wraz z upływem czasu i zmianami społecznymi i politycznymi, jakie zachodziły na terenie Grecji oraz Rzymu. Nieco inny obraz starości zarysowuje się w pismach filozofów greckich, z których wielu dożyło późnego wieku i zachowało dobrą kondycję fizyczną. Jak zauważa w swej monografii cytowany wyżej Minois: „Rozmyślali [oni] często o tajemnicy starości. Obfitość pism, jakie stworzyli na ten temat świadczy o zainteresowaniu, a zarazem o zakłopotaniu, jakie w nich budził" je tak: „Żaden z owych mędrców nie twierdził, że starość, jako taka jest czymś dobrym, i jest to znamienne wyznanie. Wszyscy ci starcy akceptują swój wiek jedynie dotąd, dokąd towarzyszy mu zdrowie. [...] Filozofowie, podobnie jak inni ludzie, niechętnie godzą się ze swą starością. Zauważają, że pomimo wszelkich bolączek podeszłego wieku wszyscy chcą go osiagnąć. [...] Należy oczywiście szanować starców, jak się tego domagali Chilon i Pitagoras. Także i stoicy nauczali, że rodziców należy czcić zaraz po bogach. W sumie jednak

${ }^{4}$ Por. Homerus, Odyssea II 179, ed. V. Bérard: Homére, L’Odyssée, Les Belles Lettres, Paris

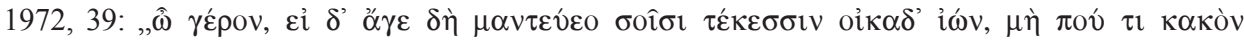
$\pi \alpha ́ \sigma \chi \omega \sigma \imath v$ ỏ $\dot{i}^{\sigma} \sigma \sigma \omega$ " (,Starcze, idź do domu wieszczyć swoim dzieciom, żeby coś złego cię nie spotkało").

${ }^{5}$ Por. Hesiodus, Theogonia 211-225, tłum. J. Łanowski: Hezjod, Narodziny bogów. Prace i dni. Tarcza, Warszawa 1999, 38.

${ }^{6}$ Por. Mimnermus, frg. 1(7), thum. W. Appel, w: Liryka starożytnej Grecji, BN II 92, wyd. 2, Wrocław 1984, 295-296: „Skoro przykra nadejdzie / starość, która zeszpeca nawet pięknego człowieka, / Wówczas serce bez przerwy niedobre troski nękają, / Także nie cieszy już więcej widok słonecznych promieni, / Wnet też niemiły się stajesz dla kobiet i dla chłopców. / Tak to bóg człowiekowi starość bolesną sposobi”.

7 Najbardziej charakterystyczny fragment por. Sophocles, Oedipus Coloneus 1224-1237, thum. R. Chodkowski: Sofokles, Edyp w Kolonos, w: Sofokles, Tragedie, Lublin 2009, 482: „Najważniejsze - się nie rodzić / Druga rada: gdy już żyjesz, / odejść szybko, / skąd przyszedłeś. / Bo gdy minie czas młodości, / lekkomyślny i szalony, / jaki cios lub trud jaki nas nie sięgnie? / Kto uniknie cierpień, bólu,/ morderstw, buntów, sporów, walki / i zawiści? Potem zaś nadchodzi starość / nienawistna i bezsilna, i samotna, /bez przyjaciół, z którą żyją w jednym domu / wszystkie już najgorsze biedy". Podobne wzmianki na temat starości znajdziemy też u Ajschylosa w Agamenonie, oraz u Eurypidesa w Fenicjankach, Hekabe i Heraklesie oszalatym.

${ }^{8}$ Minois, Historia starości, s. 63-64. 
filozofowie czują zakłopotanie wobec starości, która przysparza im więcej cierpień aniżeli autorytetu i mądrości"9.

Oczywiście zdecydowanie odbiega od tych poglądów stanowisko Platona, wyłożone szczegółowo w jego Państwie oraz Prawach, które ukończył około roku 348-347, w wieku osiemdziesięciu lat ${ }^{10}$. Przedstawia on tam idealny obraz starca i gerontokracji w utopijnym państwie. Ogromne przywileje jakie Platon przyznaje starcom mogą świadczyć, zdaniem Minois, z jednej strony o podziwie, jaki żywił dla ustroju spartańskiego, a z drugiej o jego niezadowoleniu $\mathrm{z}$ trudnego położenia starców w Atenach i z pragnienia zmiany tejże sytuacji ${ }^{11}$.

Spojrzenie odmienne od obiegowego, negatywnego postrzegania starości jako wieku degradacji fizycznej, a nawet etycznej człowieka, a także odmienne od platońskiego - idealnego postrzegania osoby i roli starca w społeczeństwie, przyniosła filozofia stoicka, a zwłaszcza ostatni etap jej rozwoju, czyli tak zwana późna Stoa lub neostoicyzm, rozwijająca się na terenie Grecji i Rzymu w okresie cesarstwa. Przyjrzyjmy się zatem, jak widzieli starość i rolę ludzi w podeszłym wieku trzej główni przedstawiciele późnej Stoi, a mianowicie Seneka (1-65), Epiktet (50/60-138) oraz Marek Aureliusz (121-180).

Neostoicy skupili swe zainteresowania filozoficzne głównie na dziedzinie etyki. A zatem ich filozofia jest filozofią moralną - odnoszoną do praktycznej sfery życia. Myśl filozoficzna przedstawicieli późnej Stoi ulega wpływom medioplatońskim, a także znajdujemy $\mathrm{w}$ niej elementy zaczerpnięte $\mathrm{z}$ innych szkół epoki hellenistycznej: cyników, epikurejczyków czy sceptyków ${ }^{12}$. Należy jednak podkreślić, że, pomimo tego pewnego eklektyzmu, metoda uprawiania filozofii, jaką neostoicy proponowali, opiera się na przyjęciu zasad fizyki stoickiej, czyli materialistycznej, a jednocześnie panteistycznej wizji kosmosu, przenikniętego przez boską pneumę, czy też logos, który kształtuje materię według określonych zasad, nadając jej formę celową i zorganizowana. Wyjaśniali oni w ten sposób nie tylko samą budowę wszechświata, lecz przede wszystkim miejsce i rolę wszystkiego, co człowieka w tym świecie otacza, a co za tym idzie, plasuje go na miejscu jemu właściwym ${ }^{13}$.

\footnotetext{
${ }^{9}$ Por. tamże, s. 66-67. Między innymi stoik Hierokles podkreśla tradycyjne powinności dzieci wobec rodziców, zob. Stobajos IV 640, 4 - 644, 15; por. też: Diogenes Laertios, De vitae philosophorum VII 7-9, thum. W. Olszewski: Żywoty i poglądy stynnych filozofów, Warszawa 2004, 373373C (stoik Zenon musiał zrezygnować z zaproszenia na dwór macedońskiego króla Antigonosa $\mathrm{z}$ powodu podeszłego wieku).

${ }^{10}$ Por. Plato, Respublica 412c, VI 497e, VI 498bc, VII 536cd, VII 540a; Leges I 635ac, II 658de, VI 755a, VII 802b, VIII 846c, X 888ab, XI 917a, XI 965a, XI 983a.

${ }^{11}$ Por. Minois, Historia starości, s. 70: „[...] szczególne względy, jakimi otacza starców, szacunek, jakim cieszą się w idealnym mieście, uprawnienia, które zostają im przyznane w jego utopii wyraźnie wskazują na ich niską pozycję i fakt, że byli odrzucani w rzeczywistym społeczeństwie. Są oznaką reakcji filozofa na stan rzeczy, jaki pragnął odwrócić”.

${ }^{12}$ Por. G. Reale, Historia filozofii starożytnej, IV, tłum. E.I. Zieliński, Lublin 1999, 99, 128-129 i 150.

${ }^{13}$ P. Hadot (Twierdza wewnętrzna, tłum. P. Domański, Kęty 2004, 87-88) zwraca uwagę na
} 
„Dyskurs fizyczny miał uzasadnić wybór życiowy i objaśnić wynikający zeń sposób życia w świecie. Podobnie jak u epikurejczyków, również u stoików fizykę uprawia się nie przez wzgląd na nią samą, lecz w pewnym celu etycznym [...]. Można od razu stwierdzić, że stoicka fizyka potrzebna jest etyce, gdyż uczy człowieka, ze istnieją rzeczy poza jego władzą, zależne od przyczyn w stosunku do niego zewnętrznych, łączące się ze sobą w sposób konieczny i rozumny" ${ }^{14}$. Marek Aureliusz miejsce człowieka we wszechświecie i rolę jego działania widzi w następujący sposób:

„Przede wszystkim nie trać spokoju: wszystko bowiem dzieje się zgodnie z wszechnaturą. [...] wszechnatury czynność na tym polega, że co jest tu, przestawia tam, przemienia, stąd unosi, a tam zanosi. Wszystko polega na zmianie układu. Tak że nie ma obawy, by stało się coś nowego. [...] Wszelkie stworzenie czuje zadowolenie wewnętrzne, gdy idzie dobrą drogą. Stworzenie zaś rozumne wtedy idzie dobrą droga, gdy w swych wyobrażeniach nie ma poczucia fałszu i niejasności, gdy kieruje swe dążenia jedynie ku wspólnemu dobru, a w swych pragnieniach i wstrętach ogranicza się do tego, co tylko od niego samego zależy, i gdy chętnie się zgodzi na to, co mu wszechnatura wydziela. Jest przecież jej cząstką jak natura liścia - natury rośliny. $Z$ tą tylko

fakt, iż przejęty przez stoików podział filozofii na dialektykę, fizykę i etykę, który funkcjonował już w szkole platońskiej, nabrał w ich ujęciu zupełnie odmiennego charakteru. U Platona podział ten był wyraźnie shierarchizowany - dialektyka stanowiła część najszlachetniejszą, gdyż odnosiła się do świata idei, fizyka - przedmiotem której były zjawiska świata widzialnego, zajmowała pomniejsze stanowisko, a etyka, badająca przypadkowe działania ludzkie zajmowała pozycję najniższą: „Stoicy, przejmując ten podział, całkowicie go przekształcili: terminologia wydaje się zachowana bez zmian, a jednak stanowi wyraz już nie hierarchii platoników, lecz dynamicznego i unitarnego pojmowania świata właściwego stoikom. W trójcy: fizyka, etyka i dialektyka, nie istnieje już wyższość jednej dyscypliny nad innymi, gdyż wszystkie odnoszą się do tego samego logosu, do tego samego boskiego Rozumu obecnego w świecie fizyki, w świecie życia społecznego [...], oraz w ludzkim słowie i myśli, czyli w rozumnym działaniu osądu. Ponadto [...] owe trzy dyscypliny warunkują się wzajemnie, bo ten sam logos, ten sam Rozum odnajduje się przyrodzie, we wspólnocie ludzkiej i w indywidualnym rozumie. [...] Dla stoików cała rzeczywistość jest jednorodna, a zazębianie się i łączenie ze sobą zdarzeń - całkowicie konieczne"; zob. też: A. Krokiewicz, Zarys filozofii greckiej, Warszawa 2000, 462. Według Diogenesa Laertiosa (De vita philosophorum VII 138-139, thum. K. Leśniak: Żywoty i poglady stynnych filozofów, Warszawa 1988, 432) Chryzyp i Posejdonios ujmowali tę jedność materii i rozumu w następujący sposób: „Świat jest kierowany

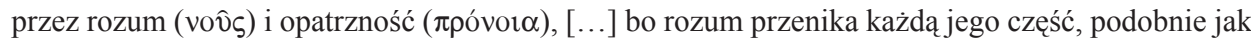
dusza w człowieku, ale pewne części więcej, inne zaś mniej. W jednych ujawnia się jako sprawność,

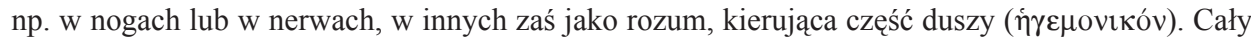

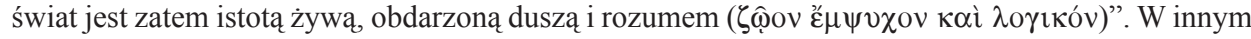
miejscu (tamże VII 140, tłum. Leśniak, s. 433) czytamy: „W samym świecie nie ma próżni, lecz tworzy on zwartą jedność. Jest konieczne następstwo wewnętrznego związku i harmonii $(\sigma 0 ́ \mu \pi v o t \alpha$

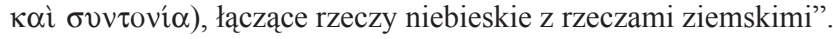

${ }^{14}$ P. Hadot, Czym jest filozofia starożytna?, tłum. P. Domański, Warszawa 2000, 171-172. Hadot przywołuje w tym miejscu Stoicorum Veterum Fragmenta (= SVF) III 68: „Fizyki uczy się tylko po to, by móc uczynić rozróżnienia, jakie trzeba przeprowadzić między tym, co dobre, a tym, co złe". 
różnica, że natura liścia jest cząstką natury nieczułej i nierozumnej, i zdolnej do ujarzmienia, a natura człowiecza jest częścią natury nieujarzmialnej i rozumnej, i sprawiedliwej. Bo wszystkim równych i stosownie do ich wartości udziela cząstek czasu, materii, przyczyny, energii i przygód"15.

Przeprowadzenie rozróżnienia między rzeczami zależnymi a niezależnymi od

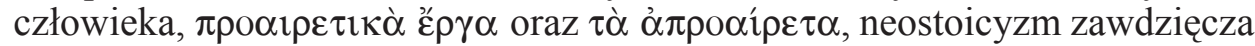
przede wszystkim Epiktetowi, który wprowadził ten podział zamiast głównej zasady etycznej dawnej Stoi, która dzieliła rzeczy na dobre, złe i obojętne ${ }^{16}$ :

„Zależne są od nas: sądy, popędy, pragnienia, odrazy i jednym słowem - to wszystko, co jest naszym dziełem. Niezależne natomiast są od nas: ciało, mienie, sława, godności, i jednym słowem - to wszystko, co nie jest naszym dziełem. I dlatego te rzeczy, które od nas zależą, z natury są wolne i nie podlegają żadnym zakazom ani przeszkodom, te natomiast, które od nas nie zależą, nie przedstawiają żadnej wartości, spełniają służebną rolę i stanowią cudzą własność"17.

Warto też podkreślić, zwłaszcza w przypadku Seneki, a także Epikteta, wielką rangę, jaką nadają oni bóstwu i opatrzności bożej, przejawiającej się we wszystkich procesach zachodzących we wszechświecie, a co za tym idzie również w życiu każdego człowieka. Epiktet stwierdza bardzo wyraźnie:

„Za wszystko, co się dzieje w świecie, łatwo jest wielbić opatrzność, jeżeli ma ktoś w sobie dwie zalety: zdolność postrzegania dobrodziejstw, które mu przypadły w udziale, i wdzięczność. [...] Jeżeli zatem każde z dzieł ludzkich jawnie wskazuje na mistrza, to czyliż rzeczy widzialne i samo widzenie, i światło nie miałyby jawnie na niego wskazywać?"18.

Człowiek jest istotą zajmującą miejsce szczególne w świecie, a co za tym idzie istotą, na której spoczywają również szczególne zobowiązania:

„Jeśli ktoś, jak przystało, do głębi serca zdoła się przejąć tą wiarą, że wszyscy początki naszego rodu wywodzimy od boga i że on jest ojcem bogów i ludzi, ten, moim zdaniem, nie będzie myślał o sobie niczego podłego ani pospolite-

${ }^{15}$ Marcus Aurelius, Ad se ipsum VIII, 5-7, tłum. M. Reiter: Marek Aureliusz, Rozmyślania, Biblioteka Klasyków Filozofii 42, Warszawa 1958, 88-89.

${ }^{16}$ Reale (Historia filozofii starożytnej, IV, s. 129) uznaje wprowadzenie tak przeformułowanego podziału za podstawową zasadę etyki Epikteta.

${ }^{17}$ Epictetus, Encheiridion 1, ed. W.A. Oldfather: Epictetus, The Discourses, The Manual, Fragmenta, II, Loeb, Cambridge - London 1959, 482, thum. L. Joachimowicz: Epiktet, Diatryby Encheiridion, Biblioteka Klasyków Filozofii 64, Warszawa 1961, 455; por. też: Diatryby I 22, thum. Joachimowicz, s. 73: „Co więc znaczy czynić postępy w nauce? Znaczy to uczyć się, jak w poszczególnych wypadkach stosować w sposób właściwy naturalne pojęcia ogólne, a dalej, jak dostrzegać różnicę, że mianowicie jedne rzeczy od nas zależą, a drugie nie zależą. Zależą od nas: wolna wola i wszystkie czyny płynące z wolnej decyzji. Nie zależą natomiast od nas: ciało, części ciała, mienie, rodzice, bracia, dzieci, ojczyzna i w ogóle cała społeczność".

${ }^{18}$ Epictetus, Dissertationes I 6, 1-8, ed. Oldfather, s. 40, thum. Joachimowicz, s. 21. 
go. Naprawdę, gdyby cesarz przybrał ciebie za syna, chełpiłbyś się tym nie do zniesienia. lecz gdy ci wiadomo, że jesteś synem Zeusa, nie będziesz wbijać się w dumę? [...] Przy naszym poczęciu owe dwie części - ciało wspólne ze zwie-

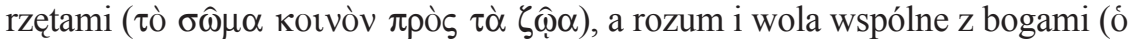

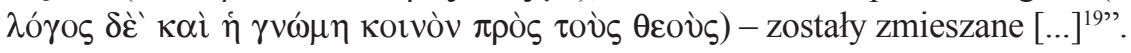

Jeżeli człowiek skupi się na swym przywiązaniu do ciała, upodobni się do zwierząt - stanie się dziki, okrutny, podstępny. Człowiek urodził się po to, aby podziwiać boga i jego dzieła, a także, aby dzieło to thumaczyć i prowadzić zgodne z rozumną naturą życie. Powinien też uważać, aby nie zaskoczyła go śmierć zanim zdąży spełnić to zadanie ${ }^{20}$. Dlatego też nie wolno mu zrażać się przeciwnościami, a wręcz przeciwnie - wykorzystywać je na drodze swego moralnego rozwoju, i dziękować za nie bogu, gdyż pokonanie ich nie przekracza sił człowieka. Podobnie Herakles nie stałby się Heraklesem, gdyby nie musiał zmierzyć się z tyloma niebezpieczeństwami ${ }^{21}$.

Epiktet zdaje się w ogóle nie przywiązywać żadnej szczególnej wagi do wieku - zwraca jedynie uwagę na krótkotrwałość życia, która może nam przeszkodzić w naszym doskonaleniu moralnym. Jeśli już wspomina o starości, czyni to jakby mimochodem:

„Najważniejszą i najuroczystszą pieśń dziękczynienia wznosić trzeba nam za to, że bóg dał nam zdolność wnikania rozumem w istotę rzeczy i czynienia z nich należytego użytku. [...] Bo i co innego potrafię ja, chromy staro-

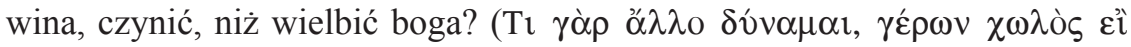

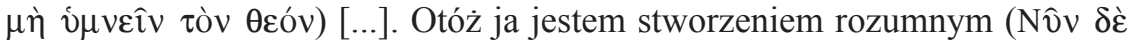

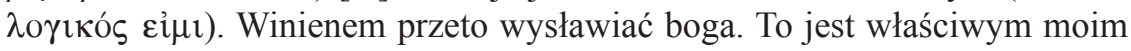
zadaniem. Rad więc je spełniam"22.

Panteistyczne pojmowanie bóstwa i świata przez stoików kształtowało ich poglądy na rolę i zadania człowieka w tymże świecie, a co za tym idzie miało wpływ na poglądy dotyczące starości, i w ogóle problemu długości czy krótkości życia. Szczególne ujęcie bóstwa u Seneki jest z jednej strony ujęciem panteistycznym, zgodnym z zasadami starej Stoi, a z drugiej wykracza poza utożsamienie boga z naturą i rozumem, przenikającym wszechświat. Seneka podkreśla bardzo osobistą relację człowieka z bóstwem, w szczególności człowieka prawego, żyjącego zgodnie z nakazami rozumu, nie poddającego się zmiennym okolicznościom zewnętrznym ani namiętnościom:

${ }^{19}$ Tamże I 3, 1-3, ed. Oldfather, I, s. 24, thum. Joachimowicz, s. 14.

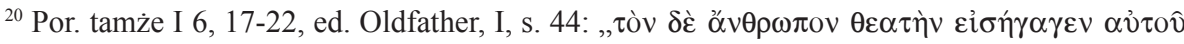

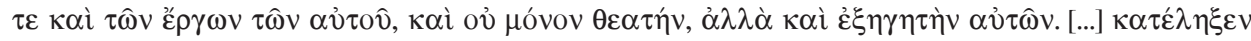

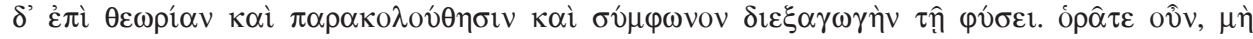

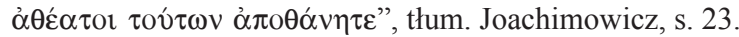

${ }^{21}$ Por. tamże I 6, 32-36, ed. Oldfather, I, s. 46-48, thum. Joachimowicz, s. 24-25.

${ }^{22}$ Tamże I 16, 20-21, ed. Oldfather, I, s. 112, thum. Joachimowicz, s. 57. 
„Przebywa w nas święty duch, który widzi i pilnuje wszystkich naszych złych i dobrych uczynków. [...] Nikt zaiste nie może być mężem prawym bez Boga" (Sacer intra nos spiritus sedet, malorum bonorumque nostrorum observator et custos [...]. Bonus vero vir sine deo nemo est $)^{23}$.

Bóg zatem, czy też jego cząstka zamieszkująca w człowieku, „uodparnia” go na wszelkie przeciwności losu i pomaga w znoszeniu ich z niewzruszonym spokojem, ale też w specyficzny sposób hartuje człowieka, stawiając przed nim wysokie wymagania. Bóg postępuje tak jak ojciec, który nie rozpieszcza swoich dzieci, ale kształtuje ich charaktery poprzez surowe postępowanie. A zatem wszelkie trudności i przykrości, również i te związane z podeszłym wiekiem, z którymi człowiek szlachetny spotka się w życiu, są dowodem szczególnej bożej opieki i okazją do duchowego rozwoju ${ }^{24}$.

Tak ukształtowana wizja wszechświata i bóstwa - (czy to traktowanego bardziej, czy mniej panteistycznie) staje się podstawą do ujęcia poszczególnych zagadnień, związanych już bezpośrednio z życiem człowieka, a więc i zagadnienia starości. Świat - to jeden żywy organizm - harmonijny i doskonały, w którym zachodzą pewne nieuchronne procesy, takie jak starzenie się, choroby, czy naturalna utrata sił, którym to procesom należy się podporządkować i przyjąć ich nieuchronność ze spokojem. Nie są one w żaden sposób zależne od woli człowieka, a zatem stoik nie uznaje ich za rzeczy złe czy dobre, lecz po prostu za obojętne,

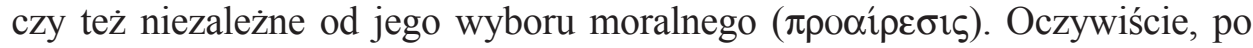
przyjęciu takich założeń nie sensu ani narzekanie na niedogodności związane z wiekiem podeszłym, ani bunt, zaprzeczanie pewnym ograniczeniom wynikającym z tegoż wieku. Należy ocenić te niedogodności jako fakty, które nie są w stanie dotknąć tej boskiej cząstki, jaka w nas tkwi, a mianowicie naszej zdolności rozumowania i dokonywania wolnego wyboru ( $\pi \rho \circ \alpha i \rho \varepsilon \sigma ı)$ ). Pamiętając więc o tym, należy tak zestroić swój sposób myślenia $(\gamma \vee \omega ́ \mu \eta)$ i mniemania

${ }^{23}$ Seneca, Epistulae 41, 1-2, ed. L.D. Reynolds: L. Annaei Seneca ad Lucilium epistulae morales, Oxonii 1965, 108, thum. W. Kornatowski: Seneka, Listy moralne do Lucyliusza, Biblioteka Klasyków Filozofii 65, Warszawa 1961, 138. I dalej (tamże 4-5): „Jeśli spotkasz człowieka nieustraszonego w niebezpieczeństwach, nietkniętego przez pożądania, szczęśliwego wśród przeciwności, pogodnego wśród burz, z góry spoglądającego na ludzi, a jako równy patrzącego na bogów, to czyż nie obudzi się w tobie uwielbienie dla niego? [...] Nie może stać się tak wielka istność bez poparcia ze strony mocy boskiej".

${ }^{24}$ Seneca, De providentia I 6, ed. R. Waltz: Sénèque, Dialogues IV, Les Belles Lettres, Paris 1927, 11-12, thum. L. Joachimowicz: Lucjusz Anneusz Seneka, Dialogi, Warszawa 1989, PAX, 584-585: „Dobry człowiek różni się tylko czasem trwania od boga. Jest jego uczniem, współzawodnikiem i prawdziwym potomkiem, którego wspaniały ojciec bezwzględnie wymaga cnotliwych uczynków i zwyczajem surowych ojców rodziny wychowuje go z większą karnością. Ilekroć więc zobaczysz, że ludzie dobrzy i mili bogom trudzą się w pocie czoła, że wspinają się po stromych skałach, źli zaś beztrosko używają uciech i opływają w rozkosze, [...] tak samo jasne zrozumienie miej również w odniesieniu do boga: nie rozpieszcza rozkoszą dobrego człowieka, ale doświadcza, hartuje i czyni go sobie podobnym". 
$(\delta o ́ \gamma \mu \alpha \tau \alpha)$, z aktualną sytuacją zewnętrzna, aby „dostosowywać siebie do biegu wydarzeń, a nie bieg wydarzeń do siebie" ${ }^{25}$. A zatem jako fakt pozostający poza sferą działalności i poza wpływem człowieka, problem starości nie powinien zajmować umysłu mędrca dążącego do osiągnięcia cnoty, czyli do życia zgodnego $\mathrm{z}$ jego rozumną natura.

Mówiąc o stoickich poglądach na temat starości nie sposób nie zauważyć, iż wynikają one nie tylko ze stoickiej, panteistycznej koncepcji człowieka i kosmosu, ale również z powiązanej z nią koncepcji czasu. Stoicy przyjmowali bowiem cykliczną zmienność wszechświata - wszystko co istnieje już było i powtórzy się znowu. A zatem historia poszczególnych jednostek zostaje włączona do całej historii kosmosu:

„Cóż bowiem jest wyjątkiem nie narażonym na niebezpieczeństwo zmiany? Nie należy tu ani ziemia, ani niebo, ani cały ten układ związanych ze sobą wszechrzeczy, choć powstaje za sprawą Boga. Nie zawsze zachowa on ten porządek: nadejdzie jakiś dzień, który zepchnie go z oznaczonej drogi. Wszystko się dzieje w oznaczonym czasie (certis eunt cuncta temporibus), wszystko powinno zrodzić się, wyrosnąć i zginąć. Cokolwiek widzisz toczącego się nad nami, jak również to, wśród czego znajdujemy się i przebywamy jako pośród najtrwalszych rzeczy, zniszczeje i byt swój zakończy. Każda rzecz ma swoją starość (nulli non senectus sua est): choć w nierównych odstępach czasu, natura każe wszystkiemu iść w to samo miejsce. Cokolwiek jeno istnieje, istnieć przestanie; nie zginie, ale będzie rozproszone. Nam się zdaje, że być rozproszonym to znaczy zginąć. Otóż patrzymy bardzo niedaleko. Tępa myśl nasza, która oddała się w niewolę ciała, nie stara się zobaczyć rzeczy dalszych; inaczej z większym męstwem godziłaby się na skon własny i swoich najbliższych, gdyby zdawała sobie sprawę, że podobnie jak wszystko inne, tak też życie i śmierć przychodzi na przemiany: że to, co jest złożone rozprasza się, a to, co rozproszone, znów składa się w całość; że w tych przemianach przejawia się odwieczna biegłość (ars aeterna) kierującego wszystkim Boga (cuncta temperantis dei)"26.

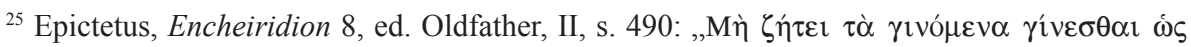

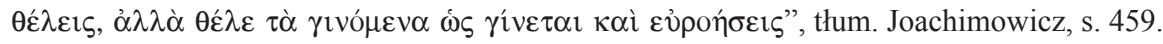

${ }^{26}$ Seneca, Epistulae 71, 12-14, ed. Reynolds, s. 212, thum. Kornatowski, s. 267-268. Myśl ta powraca wielokrotnie w pismach Seneki, por. opracowanie tego zagadnienia: C. Lévy, Sénèque et la circularité du temps, w: L'ancienneté chez les anciens, Lienhart 2003, 491-509; zob. też Epictetus, Dissertationes III 24, 10, ed. Oldfather, II, s. 186, thum. Joachimowicz, s. 303: „Świat ten cały jest

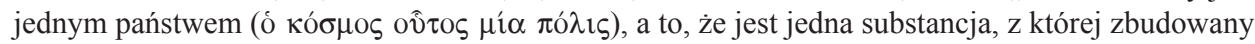

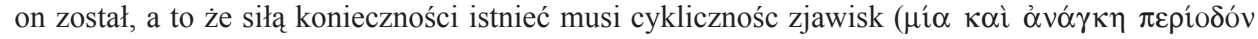
$\tau \imath v \alpha$ عîv $\alpha$ ), a to, że jedne jestestwa muszą ustępować miejsca drugim jestestwom, a to że jedne $\mathrm{z}$ nich muszą przemijać, a drugie powstawać, jedne pozostawać w tym samym miejscu, a drugie poruszać się z miejsca na miejsce”. 
W bardzo podobnym tonie, podkreślając tę cykliczną zmienność ${ }^{27}$, wypowiada się Marek Aureliusz:

„Kolisty bieg wszechświata jest zawsze ten sam: w dół, w górę, z wieczności

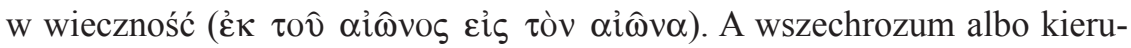
je swe postanowienia ku każdemu z osobna, (a jeżeli tak, to przyjmij z uległością skutek jego postanowienia), albo jedno raz postanowienie powziął, a reszta zdarzeń jest skutkiem lub wypływa jedno z drugiego. [...] Wnet nas wszystkich pokryje ziemia. Następnie i ona ulegnie przemianie. [...], a kto się zastanawia nad falowaniem i szybkością zmian i przemian, gardzić będzie tym wszystkim, co śmiertelne"28.

Wobec tak widzianych losów świata i losów poszczególnych jednostek kwestia krótkiego czy długiego życia traci całkowicie swoje znaczenie. Zarówno człowiek młody jak i stary może dobrze wykorzystywać swe życie - gardząc tym, co śmiertelne i wpisując swe życie w ustalony przez boski rozum cykl zdarzeń:

„Pomnij [...] ileż to sposobności otrzymałeś od bogów, a z nich nie korzystasz. Raz już należy odczuć, jakiego świata jesteś cząstką i jakiemu to władcy swój początek zawdzięczasz. I że mamy wymierzony kres czasu. A jeżeli go nie użyjesz dla uzyskania pogody ducha, zniknie on i ty znikniesz, a po raz drugi nie powróci" ${ }^{29}$.

Nieco odmiennie niż Epiktet i Marek Aureliusz potraktował zagadnienie przemijania i upływu czasu Seneka. Jako jedyny z przedstawicieli neostoicyzmu często nawiązuje bezpośrednio, właśnie w kontekście tego ciągłego przemijania, do problemu starości ${ }^{30}$. Bardzo znamienny jest jego List 12, który można by zatytułować: De senectute: Seneka konfrontuje w nim świadomość własnej starości: senectus z obrazem świata zewnętrznego, który uległ procesowi starzenia się - vetustas: „W którąkolwiek zwrócę się stronę, wszędzie widzę dowody mojego zestarzenia się" (argumenta senectutis meae video) ${ }^{31}$.

${ }^{27}$ Ta wyraźna teza heraklitejska została, zdaniem G. Reale (Historia filozofii starożytnej, IV, s. 150), przejęta przez cesarza stoika za pośrednictwem sceptyka Ainezydemosa, i może ona zakłócać nieco pogodny obraz stoickiego kosmosu.

${ }^{28}$ Marcus Aurelius, Ad se ipsum IX 28, ed. Trannoy, s. 103, thum. Reiter, s. 109; Marek nie odbiera tego przemijania i zmienności wszystkiego z poczuciem smutnej rezygnacji czy rozpaczy. Stara się nawet w przemijaniu podkreślić pozytywny aspekt: „W następstwie rzeczy po sobie następujących widać zawsze pewien związek. Bo nie jest to jakoby wyliczenie szczegółów bez związku, połączonych tylko w myśli, ale połączenie rozumne", por. tamże IV 45.

${ }^{29}$ Ad se ipsum II 4, ed. Trannoy, s. 11, thum. Reiter, s. 13; por. też II 11-12.

${ }^{30}$ Przede wszystkim Seneka pozostawił po sobie znacznie bogatszą spuściznę literacką niż Epiktet, czy Marek Aureliusz. Rozmyślania tego ostatniego, podzielone przez późniejsze redakcje na $12 \mathrm{ksiag}$, to w sumie niewielki zbiorek luźnych zapisków. Nieco więcej materiału do poznania myśli Epikteta dostarczają Diatryby, spisane ręką jego ucznia Arriana, ale w porównaniu z ilością materiału, z jakim mamy do czynienia w przypadku Seneki, pozostają znacznie mniejszą cząstką.

${ }^{31}$ Seneca, Epistulae 12, 1, ed. L.D. Reynolds, s. 26, thum. W. Kornatowski, s. 36. 
Z pewną autoironią opisuje tu swoją reakcję na nagły i nieoczekiwany dla niego obraz walącego się domu, podsychających drzew, które sam ongiś sadził, czy starego niewolnika, którego zapamiętał jako małego chłopca.

Konfrontacja ta przebiega więc na trzech płaszczyznach: a) przedmioty nieożywione - dom, kamienie; b) świat roślin - stare drzewa; c) świat ludzi - stary niewolnik. Seneka poprzez wprowadzenie tej anegdotki stosuje świadomy zabieg literacki (możemy podobny topos znaleźć u Horacego ${ }^{32}$ ). Ma ona posłużyć do przeprowadzenia filozoficznej argumentacji na rzecz zaakceptowania zarówno przemijalności i nieuchronnych zmian we wszystkim, co nas otacza, jak i zaakceptowania własnej starości ${ }^{33}$.

Podkreślanie przemijalności, krótkotrwałości i znikomości wszystkiego

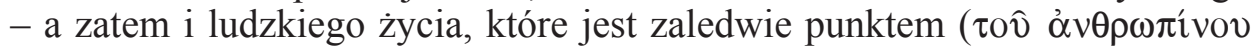

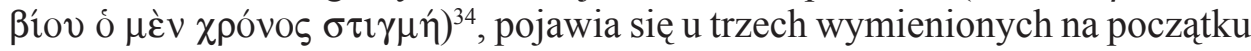
autorów bardzo często, $\mathrm{z}$ tym, że nie jest nacechowane pesymizmem (przynajmniej w ich założeniu - może największa nutka pesymizmu pobrzmiewa u Marka Aureliusza), i nie ma służyć wpędzaniu się rozpacz i depresję, ale ma przypomnieć o obowiązku wypracowania w sobie właściwej hierarchii dóbr: pierwsze miejsce zajmować powinny dobra moralne - cnota, czyli życie zgodne z rozumną naturą. Przyjęcie takich założeń ma wnosić element pewnego rodzaju pocieszenia wobec nieuchronnego końca życia ludzkiego. Rzeka wydarzeń, w którą wpisany jest los każdej jednostki wypływa z wiecznego bytu i powraca do wiecznego bytu - a zatem jednostka ta nie ginie bez śladu:

„Zrodzeni na znikomy ułamek czasu, szybko musimy ustapić miejsca innym, którzy po nas przychodzą. W takich warunkach rozglądamy się za gospodą. Mówię o długości wieku naszego istnienia, który z niewiarygodną szybkością rozpływa się w wieczność [...]. Wszystko, co ludzkie, jest krótkotrwałe i marne, i nie stanowi żadnej cząsteczki nieskończonego czasu" (De nostris aetatibus loquor, quas incredibili celeritate aevum volvit. [....] Omnia humana brevia et caduca sunt et infiniti temporis nullam partem occupantia ${ }^{35}$.

Marek Aureliusz w jednym i tym samym zdaniu nazywa życie wojna

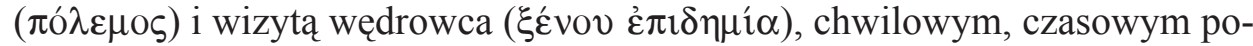
bytem cudzoziemca ${ }^{36}$, zwracając w ten sposób uwagę i na jego krótkotrwałość

${ }^{32}$ Por. Horatius, Carmina II 14.

${ }^{33}$ Por. Seneca, Epistula 12, ed. Reynolds, s. 26-29, tłum. Kornatowski, s. 36-39. Szczegółowo omawia ten list w aspekcie literackim G. Devallet, Sénèque et la vieillesse: realia et animalia devant la fuite du temps (Lettres a Lucilius I 12), w: L'ancienneté chez les Anciens, s. 511-517.

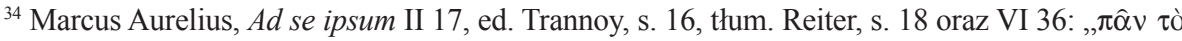

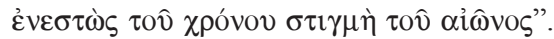

${ }^{35}$ Seneca, Ad Marciam 21, 1-2, ed. R. Waltz: Sénèque, Dialogues, II, Les Belles Lettres, Paris 1923, 42-43, tłum. L. Joachimowicz, w: L. Anneusz Seneka, Dialogi, Warszawa 1989, Pax, 443.

${ }^{36}$ Por. Marcus Aurelius, Ad se ipsum II 17, ed. Trannoy, s. 16, thum. Reiter, s. 18. Motyw życia ludzkiego jako walki Marek Aureliusz przejął zapewne od Epikteta, którego dzieło znał i stu- 
i na trudności, z jakimi musi borykać się człowiek bez względu na zajmowane przez niego stanowisko i spełniane zadania. Niezależnie od tego, czego dokonał w życiu i tak, prędzej czy późnej, czeka go zapomnienie $(\lambda \hat{\eta} \theta \eta)$. Nie powinien też oczekiwać długiego życia, gdyż śmierć może zaskoczyć go w każdej chwili, niezależnie od wieku, a zatem należy ja przyjać bez zbędnych obaw, jako element naturalny, jako swoistą przemianę ${ }^{37}$. W tej sytuacji spodziewanie się długiego życia, a traktowanie starości jako czegoś dobrego i pożądanego, stoi w sprzeczności z zasadami stoickiej filozofii i stoickiego trybu życia:

„A choćbyś miał żyć jeszcze trzy tysiące lat albo dziesięć tysięcy razy dłużej, przecież pamiętaj o tym, że nikt innego nie traci życia nad to, którym żyje, a innym nie żyje, jak tym, które traci. Najdłuższe więc równa się najkrótsze$\mathrm{mu}$. [...] jest wszystko jedno, czy się będzie patrzyło na te same rzeczy lat sto czy dwieście, czy przez wieczność. [...] i człowiek bardzo stary, i ten, który ma umrzeć we wczesnej młodości tracą po równi ${ }^{38}$.

W podobnych słowach przedstawiał ten problem Seneka, podpisując się pod charakterystyczną dla stoików teorią czasu, ujętego tylko i wyłącznie jako teraźniejszość, która jest nam dana i nad którą mamy władzę, w odróżnieniu od przyszłości i przeszłości:

„I choć mi wymienisz ludzi długo żyjących i o przekazanej pamięci potomnych starości, możesz wyliczać lat sto i sto dziesięć, jednak kiedy zwrócisz myśli na całość czasu, zniknie zupełnie różnica pomiędzy wiekiem najkrótszym i najdłuższym, jeżeli rozpatrzysz tę długość czasu, w której ktoś żył, i porównasz ją z długością czasu, w której nie żył" (Nulla erit illa brevissimi longissimique aevi differentia) $)^{39}$.

diował. Epiktet podkreśla konieczność rozumnego podporządkowania się biegowi wydarzeń, jakie nas spotykają i konieczność podejmowania zadań, jakie dana sytuacja przed nami stawia, na zasadzie posłuszeństwa, jakiego wymaga się od żołnierza pozostającego pod rozkazami dowódcy, zob. Epictetus, Dissertationes III 24, 31-34, ed. Oldfather, s. 194, thum. Joachimowicz, s. 307: „A nie wiesz ty o tym, że bojowaniem ( $\sigma \tau \rho \alpha \tau \varepsilon i ́ \alpha)$ jest żywot człowieka? Ten musi czaty odprawiać, a tamten wyruszać na zwiady, a jeszcze inny do szturmu uderzać? [...] Ty wszelako się wzdrygasz wykonać rozkazy naczelnego dowódcy, ty szemrzesz i sarkasz, ilekroć otrzymasz polecenie wykonać trudniejsze zadanie, [...] tak samo rzeczy się mają i w naszym życiu, Życie każdego człowieka jest

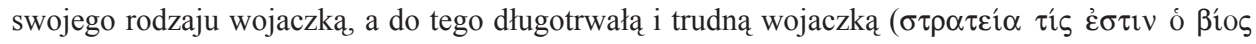

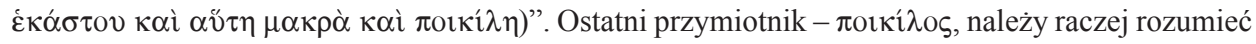
jako „zmienny, zawiły, niepewny”.

${ }^{37}$ Por. Marcus Aurelius, Ad se ipsum II 17, ed. Trannoy, s. 16, tłum. Reiter, s. 18-19: „Cóż więc może służyć za ostoję? Jedynie filozofia. A ona zasadza się na utrzymywaniu naszego demona bez zmazy i szkody, aby był silniejszy nad przyjemność i cierpienie, by nic nie czynił bez rozwagi ani w sposób fałszywy i obłudny, by nie pragnął od nikogo niczego [...] a przede wszystkim, by w każdym położeniu oczekiwał śmierci z otuchą, w przeświadczeniu, że to nic innego jak rozkład pierwiastków, z których każde stworzenie się składa".

${ }^{38}$ Tamże II 14, ed. Trannoy, s. 15, thum. Reiter, s. 17.

${ }^{39}$ Seneca, Ad Marciam 21, 3, ed. Waltz, s. 43, thum. Joachimowicz, s. 444. 
„Wykonują swe dzieło losy: odbierają nam świadomość własnego konania i aby śmierć tym łatwiej mogła niespodziewanie zaskoczyć, zataja siebie pod nazwą życia. I tak: lata niemowlęce zostają wchłonięte przez lata chłopięce, lata chłopięce przez okres wzrastania i dojrzewania, młodość porywa wiek starca" (Agunt opus suum fata; nobis sensum nostrae necis auferunt, quoque facilius obrepat mors, sub ipso vitae nomine latet [...] iuvenem senex abstulit ${ }^{40}$.

$\mathrm{Z}$ powyższych założeń wynika postawa moralna stoika wobec przemijania i śmierci - stoik nie czeka na czas wolny, jaki podaruje mu życie, gdy będzie już stary - musi w każdej chwili troszczyć się o swój duchowy i moralny rozwój i nie odkładać na później życia zgodnego z nakazami rozumu:

„Żyjecie tak, jakbyście mieli żyć wieki, że nawet nigdy nie pomyślicie o swej znikomości, że nie zwracacie uwagi, jak wiele już czasu ubyło, trwonicie go jednak w ten sposób, jakbyście zawsze mieli pełna, a nawet niewyczerpaną miarę, gdy tymczasem ten właśnie dzień, który poświęcacie bądź jakiejś osobie, bądź jakiejś sprawie, jest może - ostatni. Wszystkiego się lękacie jak śmiertelni, wszystkiego łakniecie jak nieśmiertelni” (Tamquam semper victuri vivitis, numquam vobis fragilitas vestra succurrit, non observatis, quantum iam temporis transierit; velut ex pleno et abundanti perditis, cum interim fortasse ille ipse qui alicui vel homini vel rei donatur dies ultimus sit. Omnia tamquam mortales timetis, omnia tamquam immortales concupiscitis) ${ }^{41}$.

„Jednym słowem: życie jest krótkie. Korzystaj z teraźniejszości w sposób ro-

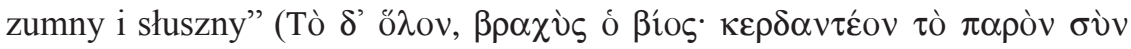

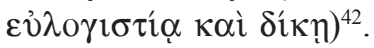

W rezultacie starość, szczególnie dla Seneki, (chociaż podobnie odbierają ten etap życia ludzkiego Epiktet i Marek Aureliusz) otrzymuje podwójny etycznie wymiar: pozytywny i negatywny, niesie z sobą zarówno szanse jak i zagrożenia dla sfery rozwoju moralnego człowieka.

A. Wymiar pozytywny starości - szanse. Seneka, pomimo stoickiej pogardy dla okoliczności zewnętrznych i przekonaniu, że należy podporządkować się całkowicie Opatrzności, wyraża jednak nieśmiałą nadzieję, iż owa Opatrzność może przedłużyć ludzkie życie, skoro sam świat uwalnia od wielu nieszczęść. Po za tym, przedłużenie życia i osiągnięcie starości zależne jest też od postępowania człowieka:

„Powściagliwość/wstrzemię́liwość może doprowadzić do starości, której co prawda, moim zdaniem, nie należy ani pragnąć, ani jej odrzucać" (Potest

${ }^{40}$ Tamże 21, 6, ed. Waltz, s. 44, thum. Joachimowicz, s. 445.

${ }^{41}$ Seneca, De brevitate vitae 3, 4, ed. A. Bourgery: Sénèque, Dialogues, II, Les Belles Lettres, Paris 1923, 51.

${ }^{42}$ Marcus Aurelius, Ad se ipsum IV 26, ed. Trannoy, s. 34, thum. Reiter, s. 37. 
frugalitas producere senectutem, quam ut non puto concupiscendam, ita ne recusandam quidem $)^{43}$.

Seneka jest przekonany o możliwości dobrego przeżywania tego ostatniego etapu ludzkiego życia:

„bylebyśmy tylko potrafili opanować i utrzymać na wodzy namiętności, przez które ginie większość ludzi. Platon, dzięki oględnemu postępowaniu sam przedłużył swój żywot aż do sędziwego wieku. [...] Wstrzemięźliwe życie, zachowanie umiaru w tym, co budzi pożądanie, tudzież staranny dozór nad sobą doprowadziły go wbrew wielu stojącym na przeszkodzie okolicznościom aż do starości”44.

Widać tu wyraźnie podziw Seneki dla postawy Platona oraz przekonanie, iż starość może być wiekiem, na który przypada szczyt intelektualnego rozwoju człowieka:

„Miło jest jak najdłużej obcować ze sobą, gdy ktoś uczynił siebie godnym tego, z czego korzysta" (Iucundum est secum esse quam diutissime, cum quis se dignum, quo frueretur, effecit $)^{45}$ - o ile człowiek oczywiście zachowa sprawny umysł i w miarę zdrowe ciało (si modo mens sine iniuria est et integri sensus animum iuvant nec defectum et praemortuum corpus est $)^{46}$.

Pomimo wyważonego i raczej przychylnego stosunku Seneki do wieku podeszłego, widać wyraźnie na podstawie tylko tych kilku wybranych fragmentów z jego pism, jak wieloma warunkami obwarowane jest, według niego, korzystanie ze starości. Człowiek nie tylko powinien przygotować się do niej przez całe życie poprzez wstrzemięźliwe i rozważne postępowanie, ale będąc już w podeszłym wieku ciągle musi ,uzasadniać” fakt, iż jeszcze żyje, udowadniać na każdym kroku, iż jest potrzebny, a jego życie nie jest zbędne. Nawet jeśli człowiek stary choruje i cierpi, ale jego umysł pozostaje sprawny, jest w stanie z pożytkiem pracować nad swym charakterem oraz nauczać tego innych ${ }^{47}$. A zatem starość zyskuje wartość etyczną wtedy, i tylko wtedy, gdy zyskuje na ważności w wymiarze społecznym.

${ }^{43}$ Seneca, Epistulae 58, 32, ed. Reynolds, I, s. 160, thum. Kornatowski, s. 204. Przyjmuję tutaj jednak thum. własne, W. Kornatowski oddaje bowiem frugalitas jako „rozwaga”.

${ }^{44}$ Seneca, Epistulae 58, 29-30, ed. Reynolds, I, s. 160: „Si voluptates, quibus pars maior perit, potuerimus regere et coercere. Plato ipse ad senectutem se diligentia protulit. [...] parsimonia tamen et eorum, quae aviditatem evocant, modus et diligens sui tutela perduxit illum ad senectutem multis prohibentibus causis", thum. Kornatowski, s. 203-204.

${ }^{45}$ Tamże 58, 32, ed. Reynolds, I, s. 160, thum. Kornatowski, s. 204.

${ }^{46}$ Tamże 58, 33, ed. Reynolds, I, s. 161, thum. Kornatowski, s. 205.

${ }^{47}$ Por. Epistulae 98, 15, ed. Reynolds, II, s. 409, thum. Kornatowski, s. 517: „Bo on sam ma już dość życia i pragnie jakiegoś przedłużenia jego nie ze względu na siebie, lecz ze względu na tych, którym jest pożyteczny. Daje dowód swej szczodrobliwości przez to, że żyje" (Nam ipse vitae plenus est, cui adici nihil desiderat sua causa, sed eorum, quibus utilis est. Liberaliter facit, quod vivit). 
W wymienionym już wcześniej liście 12 Seneka podkreśla, iż starość może być wiekiem pełnym uroku, jeśli jest właściwie wykorzystana:

„Powitajmy ją więc życzliwie i pokochajmy. Bo i ona jest pełna uroku, jeśli potrafisz z niej korzystać" (Complectamur illam et amemus; plena est voluptatis, si illa scias uti $)^{48}$.

Należy zatem przyjąć ją pogodnie, doceniając jej zalety. Powinna smakować tak, jak owoce, gdy przemijają, lub dzieciństwo, gdy się kończy - gdyż wtedy właśnie ich smak odczuwamy jako najsłodszy. Ma być ostatnim kieliszkiem wina dającym największe upojenie:

„Wszelka przyjemność na koniec przynosi to, co ma w sobie najmilszego. Najwięcej zadowolenia daje wiek już podeszły, lecz nie dochodzący jeszcze do kresu"49.

Zaraz jednak dodaje, że ten wiek u kresu też ma swoje dobre strony. Najlepszą zaś, jego zdaniem, jest ta, iż:

„W miejsce przyjemności przychodzi to, że wcale ich nie potrzebuje” (aut hoc ipsum succeditit in locum voluptatium, nullis egere). O jakże błogo jest wiedzieć, że się już uśmierzyło i ma poza sobą wybuchy namiętności!" (Quam dulce est cupiditates fatigasse et reliquisse $)^{50}$.

Seneka zaznacza, iż człowiek nawet bardzo podeszły wiekiem może spodziewać się zawsze jeszcze dodatkowego dnia życia i żywić pogodną nadzieję bez trwożliwego niepokoju:

„Jeśli Bóg dorzuci nam jeszcze dzień jutrzejszy, przyjmijmy to z zadowoleniem. Beztroskim i najszczę́liwszym panem samego siebie jest ten, kto wygląda jutra bez niepokoju. Kto powiedział sobie: «swojem już przeżył», codziennie wstaje po nowy zysk" (Crastinum si adiecerit deus, laeti recipiamus. Ille beatissimus est et securus sui possessor, qui crastinum sine sollicitudine expectat. Quisquis dixit «vixi», cotidie ad lucrum surgit $)^{51}$.

Podobnie teżEpiktetnie deprecjonuje starości jako takiej, uznaje za rzecznaturalną i dobrą wiek podeszły, przestrzega jednak przed oczekiwaniem długiego, spokojnego życia, pozbawionego trosk czy chorób, któremu nie zagraża śmierć

${ }^{48}$ Epistulae 12, 4, ed. Reynolds, I, s. 27, thum. Kornatowski, s. 37.

${ }^{49}$ Tamże 12, 5, ed. Reynolds, I, s. 27, tłum. Kornatowski, s. 37.

${ }^{50}$ Tamże.

${ }^{51}$ Tamże 12, 9, ed. Reynolds, I, s. 28, tłum. Kornatowski, s. 38-39; por. też Marcus Aurelius, Ad se ipsum VII 69, ed. Trannoy, s. 81, thum. Reiter, s. 85: „Jest cechą charakteru doskonałego, że przeżywa dzień każdy jako ostatni i ani niczym się nie trwoży, ani w działaniu nie słabnie, ani nie

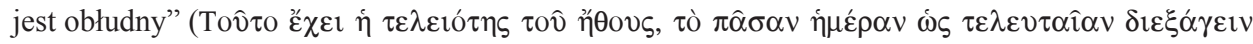

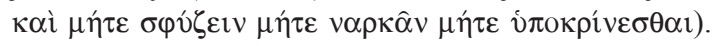


„przed czasem”. Wszelkie zmiany zachodzące w życiu ludzkim są tak nieuniknione jak zmiany w otaczającym człowieka świecie:

„Czym jesteś? Człowiekiem. Jeśli więc spojrzysz na siebie jako na jednostkę wyodrębnioną z całości, jest zgodne z natura, byś żył do późnej starości

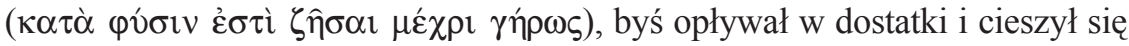
zdrowiem. Jeśli jednak spojrzysz na siebie jako na człowieka będącego cząstką pewnej całości, wypadnie tobie, dla dobra tejże całości, raz zachorować, raz znowu podróżować morzem i narażać się na niebezpieczeństwa, raz zaznać

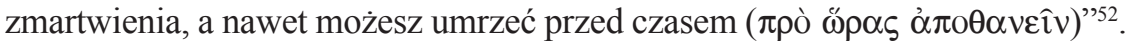

Widać tu wyraźnie, iż Epiktet, używając obiegowego określenia „przed czasem" ( $\pi \rho o ̀ ~ \dddot{\rho} \alpha \varsigma)$, wyłamuje się nieco, być może nieświadomie, ze stoickiego ujmowania biegu zdarzeń, gdzie każda zmiana, każdy fakt zachodzi zgodnie z rozumną naturą przenikniętego przez boską pneumę świata. Podkreśla on zresztą dalej, z wielkim naciskiem, że życie każdego człowieka podobne jest do rozwoju kłosa, który nie wyrasta i nie dojrzewa sam dla siebie, ale po to, aby przynieść plon i zostać zżętym:

„Wiedzcie tedy, że również dla ludzi byłoby przekleństwem, gdyby nigdy nie mieli umrzeć, podobnie jak dla kłosów, gdyby nigdy nie miały dojrzeć ani być zżęte"53.

Przyjęcie takiej postawy możliwe jest oczywiście tylko dla człowieka, który całe życie pracuje nad swoim rozwojem duchowym i uświadamia sobie zarówno nieuchronność upływu czasu, jak i nieuchronność przemijania każdego życia ludzkiego. Musi on też przyjąć do wiadomości i pogodzić się z faktem, iż kres życia może nadejść nagle, a więc pracy nad sobą nie powinien odkładać na bliżej nieokreśloną przyszłość. Stoicy wielokrotnie piętnowali daremne oczekiwania ludzkie, dotyczące długiego życia, i w konsekwencji, formułowali zagrożenia, wynikające z podeszłego wieku.

B. Wymiar negatywny starości-zagrożenia. Perspektywa nadejścia starości pociaga za sobą, zdaniem stoików, niebezpieczeństwo odkładania pracy moralnej, dla dobra duszy na starość. Tymczasem starości można po prostu nie doczekać, lub będzie ona wypełniona chorobami, cierpieniem, wszelakiego rodzaju niedogodnościami wynikającymi z podeszłego wieku. Zapominając o tych faktach, które obserwujemy na każdym kroku, zbyt wiele oczekujemy od starości. Pociaga to

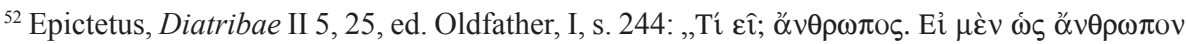

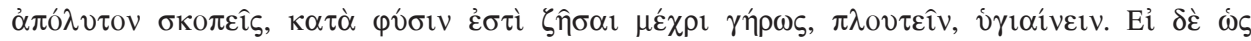

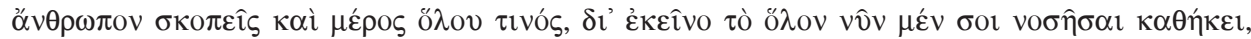

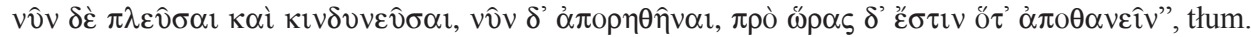
Joachimowicz, s. 119.

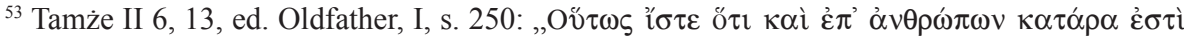

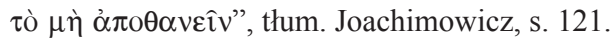


za sobą niebezpieczeństwo, że pomimo podeszłego wieku możemy umrzeć jako dzieci na poziomie moralnym, które nie zdażyły zadbać o swój duchowy rozkwit. Seneka wyraźnie ostrzega przed tym niebezpieczeństwem:
„Ale kto, koniec końców, da ci gwarancję tego dłuższego życia? Kto spra- wi, by wszystko ułożyło się według twych planów? Nie wstydzisz się, by same już resztki życia (reliquias vitae), zachować dla siebie i dla dobra duszy (bonae menti), przeznaczyć te tylko lata, kiedy już do niczego nie będziesz zdatny? O wiele za późno wtedy zaczynać dopiero życie, kiedy je trzeba już dokończyć! I cóż to za głupia niepamięć śmiertelnej doli, żeby aż na pięćdzie- siąty lub sześćdziesiąty rok życia odkładać rozumne postanowienia i chcieć rozpoczynać życie w tym wieku, do którego dożyło niewielu!"’54.

Widać tu wyraźnie określenie granic, a właściwie początku starości. Według Seneki stanowi go już pięćdziesiąty rok życia. To co dane jest człowiekowi przeżyć ponad tę liczbę, to już „resztki życia”. Można oczywiście potraktować jako retoryczną przesadę stwierdzenie, że tylko nieliczni osiagają ten wiek (lat pięćdziesiąt lub sześćdziesiąt), ale opiera się ono niewątpliwie na doświadczeniu i obserwacji, która podpowiada, iż śmierć w tym wieku nie powinna być czymś zaskakującym. Podobne refleksje pojawiają się też w Pocieszeniu do Marcji:

„[Człowiek] sprawy nieśmiertelne i wieczne snuje w swej myśli i wydaje rozporząadzenia dotyczące wnuków i prawnuków. Tymczasem kiedy na daleką przyszłość układa swe plany, śmierć je porywa, a to, co się nazywa starością, jest obrotem lat bardzo nielicznych" (Et hoc quo senectus vocatur, paucissimorum est circuitus annorum $)^{55}$.

Ci natomiast, którym uda się osiągnąć wiek podeszły, nie zachowują się, zdaniem Seneki, tak, jak przystoi ludziom rozumnym. Wraz ze starością pojawiają się kolejne wady, których pozbawione były lata młodości. Pierwszą $\mathrm{z}$ nich jest pragnienie jak najdłuższego, a nie jak najlepszego, w pojęciu stoickim, życia, które przeradza się wręcz w ciagłe żebranie o kolejny dzień i okłamywanie siebie. Ze zbytniego przywiązania do życia wynika również trwoga wielu osób w chwili śmierci - niepogodzeni z faktem, iż muszą umrzeć umierają przerażeni jej nieuchronnością:

„Zgrzybiali starcy (decrepiti senes), żebrzą w modlitwach o jeszcze kilka lat życia; wyobrażają sobie, ze przecież są młodsi. Tym kłamstwem schlebiają

${ }^{54}$ Seneca, De brevitate vitae 3, 5, ed. Bourgery, II, s. 51: „Audies plerosque dicentes: «A quinquagesimo anno in otium secedam, sexagesimo me annus ab officiis dimittet». Et quem tandem longioris vitae praedem accipis? Quis sicut disponis ire patietur? Non pudet te reliquias vitae tibi reservare et id solum tempus bonae menti destinare, quod in nullam rem conferri posit? Quam serum est tunc vivere incipere, cum desinendum est! Quae tam stulta mortalitatis oblivio in quinquagesimum annum differre sana consilia et inde velle vitam inchoare, quo pauci perduxerunt!", thum. Joachimowicz, s. 138-139.

${ }^{55}$ Seneca, Ad Marciam 11, 5, ed. Waltz, s. 26, thum. Joachimowicz, s 420. 
sobie (mendacio sibi blandiuntur), i z taką przyjemnością łudzą siebie, jak gdyby jednocześnie oszukiwali samo przeznaczenie. Lecz kiedy jakaś choroba unaoczni im konieczność śmierci, umierają w trwodze, jakby z życia nie odchodzili, ale jakby wyrywano ich siłą"56.

„Wykrzykują, że byli głupcami, ponieważ nie żyli naprawdę, ale jeśli tylko wyjdą z tej choroby w zdrowiu, będą żyli w zacisznym spokoju" 57 .

Do tego dochodzi jeszcze poczucie bezsensu przeżytego życia, jeśli ograniczyło się ono do jałowych, czczych zajęć czy do gromadzenia dóbr materialnych:

„Wtedy uświadamiają sobie, że na darmo gromadzili dobra, z których korzystać już nie będą; że na marne poszła ich praca" (Tunc quam frustra paraverint, quibus non fruerentur, quam in cassum omnis ceciderit labor $)^{58}$.

Ludzie tacy nie przeżywają życia dla siebie, to znaczy nie pracują nad swoim rozwojem duchowym, lecz rozpraszają się, pozwalając na zrabowanie sobie życia, trwoniąc je na zaspokajanie swych żądz, na kłótnie z rodziną i wierzycielami, na bezsensowną bieganinę po mieście i tym podobne sprawy. Seneka proponuje tym, którzy dożyli sędziwego wieku przeprowadzenie swoistego rachunku sumienia:

„Wybierzmy któregoś z gromady starców: «Widzimy, że dożyłeś do najdalszej granicy ludzkiego wieku. Już setny albo i wyżej niż setny rok ciąży na twoich barkach. Dalej więc! Zdaj rachunek ze swego życia! [...] Przypomnij sobie, ile to razy byłeś zdecydowany, co masz czynić, ile to dni spędziłeś tak, jak je zaplanowałeś, ile razy rozporządzałeś własną osobą, ile razy zachowałeś tę samą pogodę na twarzy, ile razy duch twój nie przejął się trwoga, jakiego w tak długim życiu dokonałeś dzieła, jak wielu ludzi rabowało ci twe życie, kiedy ty nawet nie doceniałeś, co tracisz; jak wiele ci zabrał jałowy smutek, głupia uciecha, chciwa żądza, pochlebcza rozmowa, jak mało pozostało ci z ciebie, a wtedy zrozumiesz, że umrzesz dziecięciem!» (dosłownie: jako człowiek niedojrzały - immaturus)" ${ }^{\prime 59}$.

${ }^{56}$ Seneca, De brevitate vitae 11, 1, ed. Bourgery, s. 61-62: „Decrepiti senes paucorum annorum accessionem votis mendicant; minores natu se ipsos esse fingunt; mendacio sibi blandiuntur et tam libenter se fallunt quam si una fata decipiant. Iam vero cum illos aliqua imbecillitas mortalitatis admonuit, quemadmodum paventes moriuntur, non tamquam exeant de vita, sed tamquam extrahantur", thum. Joachomowicz, s. 153-154.

${ }^{57}$ Tamże, ed. Bourgery, s. 62: „Stultos se fuisse, qui non vixerint, clamitant et, si modo evaserint ex illa valetudine, in otio victuros", tłum. własne. Otium dla Seneki jest oczywiście nie zwykłym spokojnym pogrążeniem się w lenistwie, ale uwolnieniem od zajmowania się sprawami publicznymi, państwowymi, wprowadzającymi zamęt i niepokój w życie, co uniemożliwia skupienie uwagi na pracy duchowej, wewnętrznej.

${ }^{58}$ Tamże 11, 1, ed. Bourgery, s. 62, thum. Joachimowicz, s. 154.

${ }^{59}$ Tamże 3, 2-3, ed. Bourgery, s. 50-51: „Libet itaque ex seniorum turba comprendere aliquem: 'Pervenisse te ad ultimum aetatis humanae videmus, centesimus tibi vel suprapremitur annus; agedum, 
Jak widać rachunek ten nie kończy się bynajmniej optymistyczną konkluzją, gdyż wymienieni wyżej starcy nie tylko w większej części zmarnowali swe życie, trwoniąc je na zbyteczne zajęcia, lecz także, będąc już w podeszłym wieku, dumni są z liczby przeżytych lat, lekceważąc zupełnie sposób, w jaki je przeżyli. Jednym słowem, nie dość, że źle spożytkowali dany im czas, to $\mathrm{w}$ dodatku nie zdają sobie $\mathrm{z}$ tego sprawy. Nie są zatem w stanie nawet tych ostatnich chwil przeżyć w sposób dojrzały i godny człowieka mądrego.

Kolejna grupa ludzi starszych, zasługujących, zdaniem Seneki, na naganę, to starcy, którzy pracują ponad siły, nie umiejąc trafnie ocenić swych możliwości. Szczególnie godni potępienia są ci, którzy gonią za poklaskiem i sławą, chociaż wystawiają się w ten sposób na pośmiewisko, zwłaszcza wtedy, gdy gromada pochlebców czyha na ich spadek. Seneka wypowiada się o nich w szczególnie ostrych słowach:

„Inni już w sędziwej starości (ultima senectus), gdy budowali na niej zupełnie jak na młodości nadzieje nowego życia, wśród gwałtownych i wytężonych (dosł. niegodziwych) porywów załamali się z braku sił. Hańba temu (foedus ille), w którym dech zamarł w czasie, kiedy goniąc w sędziwych swych latach za poklaskiem nierozumnego pospólstwa bronił w sądzie najnikczemniejszych pieniaczy! Hańba temu (turpis ille), kto wcześniej zmęczony życiem niż pracą padł w czasie wykonywania posług! Hańba temu, kto na łożu śmierci przyjmując rachunki stał się pośmiewiskiem dla długo na spadek czyhającego dziedzica!" ${ }^{60}$.

Przywołuje dalej postać starca Turaniusza, który dopiero w wieku 90 lat został zwolniony przez Gajusza Cezara z pełnienia obowiązków i z tego powodu kazał urządzić w swoim domu symboliczny pogrzeb - lamenty domowników miały wpłynąć na Cezara i ten, chcąc nie chcąc przywrócił go na urząd. Seneka z wyraźną pogardą komentuje takie zachowanie. Stwierdza, iż dłużej Turaniuszowi starczało chęci niż siły do pracy. Potępienie takiej postawy jest tu bardzo mocne i wyraźne. Seneka powołuje się nawet na ustawy, które w określonym czasie usuwały z zajmowanych stanowisk senatorów -65 rok życia oraz zwalniały ze służby wojskowej - 45 rok życia. Ci, którzy nie dostrzegają słuszności takiego prawa, szkodzą zarówno sobie samym, jak i innym ludziom $w$ ich otoczeniu:

ad computationem aetatem tuam revoca. [...] Repete memoria tecum, quando certus consilii fueris, quotus quisque dies ut destinaveras processerit, quando tibi usus tui fuerit, quando in statu suo vultus, quando animus intrepidus, quid tibi in tam longo aevofacti operis sit", thum. Joachimowicz, s. 137-138.

${ }^{60}$ Tamże 20, 1-2, ed. Bourgery, s. 77: „Quorundam ultima senectus, dum in novas spes ut iuventa disponitur, inter conatus magnos et improbos invalida defecit. Foedus ille, quem in iudicio pro ignotissimis litigatoribus grandem natu et imperitae coronae assensiones captantem, spiritus liquit; turpis ille, qui vivendo lassus citius quam laborando inter ipsa officia conlapsus est; turpis, quem accipiendis immorientem rationibus diu tractus risit heres", thum. L. Joachimowicz, s. 174-175. 
„Walczą z niedołęstwem ciała, co się zaś tyczy samej starości, to z tego ją tylko powodu uważają za rzecz uciążliwą, że ich usuwa od zajęć [...] zwolnienie od pracy z większą trudnością otrzymują od siebie, niż od ustawy"61.

Postępując w ten sposób stają się po za tym uciążliwi sami dla siebie a także dla osób z ich otoczenia:

„Tymczasem, kiedy tak sami pędzą i innych popędzają, kiedy jeden drugiemu zakłóca spokój i sprawia przykrości, życie ich upływa bez pożytku, bez przyjemności, bez żadnego postępu rozwoju duchowego" (Vita est sine fructu, sine voluptate, sine ullo profectu animi $)^{62}$.

Starość to nie tylko utrata sił oraz zdrowia, a co za tym idzie - bolesne dolegliwości i zabiegi lecznicze, ale człowiekowi w podeszłym wieku zagraża w nie mniejszym stopniu korupcja charakteru i upadek ducha:

„Przecież nawet szlachetne charaktery nie donoszą do wieku starczego tej samej nadziei, jaką pozwalały w stosunku do siebie żywić za czasów młodości, ale bardzo często się znieprawiają" (Neque enim recta ingenia qualem in adulescentia spem sui fecerant usque in senectutem pertulerunt, sed interversa plerumque sunt $)^{63}$.

Niektórzy mają wtedy skłonność do popadania w rozpustę, którą Seneka uważa za szczególnie obrzydliwą z tej właśnie racji, że pojawia się w podeszłym wieku. Inni zaczynają oddawać się pijaństwu i obżarstwu, troszczą się jedynie o zaspokojenie najbardziej prymitywnych popędów ${ }^{64}$. Do degradacji moralnej dochodzi też degradacja fizyczna, choroby i różne dolegliwości oraz związane z nimi przykre zabiegi lekarskie. A zatem istnieje poważne niebezpieczeństwo, iż człowiek nie zachowa do późnej starości ani piękna ciała ani piękna ducha.

Podobne obawy żywił też Marek Aureliusz - nie lękał się jednak starości i śmierci z powodu bólu i cierpień, jakie ze sobą niosą. Obawiał się, że starość osłabi jego siły fizyczne i umysłowe, a zatem nie będzie już mógł z całym poświęceniem pracować dla dobra ogółu, a nawet może stać się ciężarem dla innych:

${ }^{61}$ Tamże 20, 3-4, ed. Bourgery, s. 77, tłum. Joachimowicz, s. 175.

${ }^{62}$ Tamże 20, 5, ed. Bourgery, s. 77, tłum. Joachimowicz, s. 175.

${ }^{63}$ Seneca, Ad Marciam 22, 2, ed. Waltz, s. 45, thum. Joachimowicz, s. 446.

${ }^{64}$ Tamże 22, 2-3, ed. Waltz, s. 45: „Aut sera eoque foedior luxuria invasit coepitque dehonestare speciosa principia, aut in popinam ventremque procubuerunt toti summaque illis curarum fuit, quid essent, quid biberent. Adice incendia, ruinas, naufragia, lacerationesque medicorum ossa vivis legentium et totas in viscera manus demittentium et non simplici cum dolore pudenda curantium; post haec exilium [..], carcerem [...], voluntario vulnere transfixum pectus", thum. Joachimowicz, s. 446447. Należy pamiętać o kontekście całej tej wypowiedzi. Seneka pocieszając Marcję po śmierci syna, pragnie uwypuklić wszystkie niedogodności związane z długim życiem, a więc wylicza przerażający szereg klęsk i nieszczęść, jakie spadają na ludzi oraz cierpień, jakie zadają chorym lekarze. A im dłuższe życie, tym więcej w nim chorób i różnorakich dolegliwości. 
„Nie tylko to powinno się wziąć pod rozwagę, że co dnia zużywa się życie, ale i to, że gdyby miało się żyć bardzo długo, co jest niepewne, czy starczy równej na dalszą przyszłość bystrości, potrzebnej do zrozumienia wypadków i do zrozumienia nauki mającej na celu badanie spraw boskich i ludzkich. Gdy się bowiem zacznie dziecinnieć, pozostanie wprawdzie zdolność oddychania i karmienia się, i tworzenia wyobrażeń, i pożądanie itd., ale gaśnie zdolność władania sobą samym i umiejętnego zdawania sobie sprawy z obowiązków i porządkowania zjawisk i zdolność osądzania, czy już należy się stąd wynieść samemu, i to wszystko, co w wysokim stopniu wymaga umysłu wyćwiczonego. Należy się więc spieszyć, i to nie tylko dlatego, że każdej chwili bliżsi stajemy się śmierci, ale i dlatego, że ustaje zdolność wnikania w zdarzenia i ich zrozumienia" 65 .

\section{Cesarz-filozof mógłby więc z pewnością powtórzyć za Seneką:}

„Wiek należy do rzeczy zewnętrznych. Dopokąd mam istnieć - nie moja to rzecz. Moją sprawą jest, jak będę żył. Wymagaj ode mnie tego, iżbym niby błądząc w ciemnościach nie przepędzał mego czasu niesławnie; bym wiódł życie, a nie przeciagał tylko koło niego. Pytasz, jakie jest najdłuższe trwanie żywota? Żyć aż do osiągnięcia mądrości” (Aetas inter externa est. Quamdiu sim, alienum est; quamdiu ero, ut sim, meum est. Hoc a me exige, ne velut per tenebras aevum ignobile emetiar, ut agam vitam, non ut praetervehar. Quaeris quod sit amplissimum vitae spatium? Usque ad sapientiam vivere $)^{66}$.

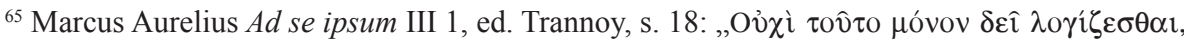

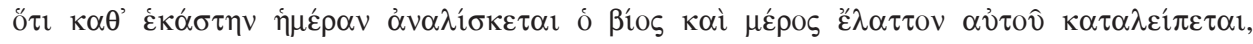

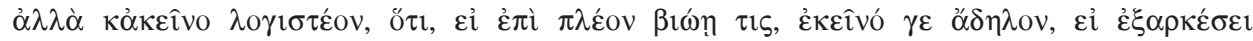

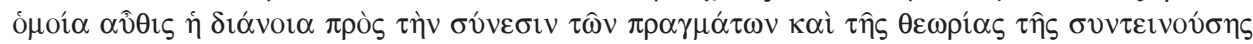

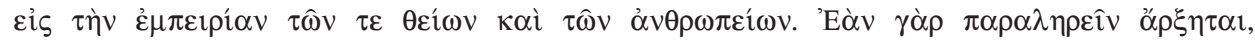

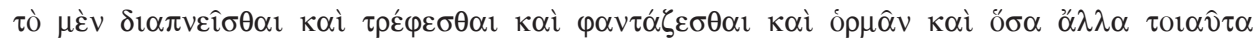

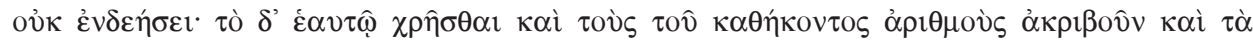

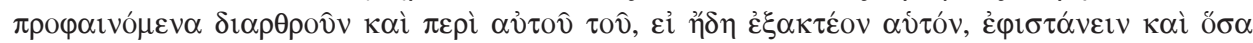

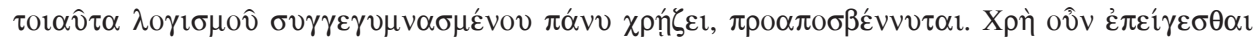

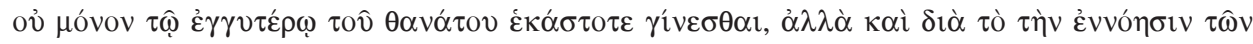

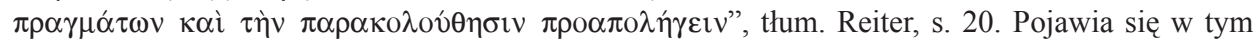
fragmencie motyw samobójstwa, które było przez stoików nie tylko dopuszczane, ale nawet zalecane w niektórych przypadkach. Wybór takiego, a nie innego zakończenia życia stoicy pozostawiali wyłącznie rozumnej decyzji człowieka, oczywiście tego, który osiągnął wysoki stopień doskonałości moralnej, por. np. F.H. Sandbach, The Stoics, London 1975, 52-53; G. Reydams-Schills, La vieillesse et les rapports humains dans le stoïcisme romain, w: L'ancienneté chez les anciens, II, s. 481489. Zalecenia takie pojawiają się bardzo często u Seneki, Epikteta i Marka Aureliusza, z uwagi jednak na bogactwo materiału związanego $\mathrm{z}$ tym zagadnieniem zostaną w tym artykule pominięte.

${ }^{66}$ Seneca, Epistulae 93, 7-8, ed. Reynolds, II, s. 362, thum. Kornatowski, s. 456. 


\section{THE OLD AGE - A CHANCE OR A THREAT \\ IN THE MORAL PROGRESS OF HUMAN BEING}

\section{(Summary)}

The old age in the ancient culture of Greece and Rome, in contrast to popular opinion, appears not to be held in high esteem by everyone. This observation can be illustrated by a lot of sources in the Greek and Roman literature. The old age has been considered as difficult and troublesome both for persons, whose were afflicted by this age, and for their family, friends and all attendants. This period of human life has been exposed to illness and the other afflictions - weakness of body and mind, less intense clarity and precision of thought.

Consequently, the old people would take active part in the social and political life only in this case, when they were in good health, in good physical and mental condition. Because of this in Greek and Roman literature can be found a lot of lamentations and complaints of the old age. Only Plato and representatives of new stoic school - Seneca, Epictetus and Marcus Aurelius formulated opposite theories about the old age.

According to Stoics' perceiving of the world and the time and cyclical changes of them, the man's nature and condition from his birth directs inevitably to his death. The whole world is ruled by God and nothing in it happens without his will. So the good and wise man will accept everything, as well the old age, and all its disadvantages. This acceptance off all that happens will bring man peace of mind and protection against whatever he may suffer. The old age - for a lover of wisdom is an occasion to develop and grow up his moral virtues and to improve his character. This intellectual and ethical process issues from human reason, which is a part of divine reason, pervasive all things in the world and all men.

The Stoics warn against a danger of a moral decline and in the old age. This corruption would be caused by direction of man's attention to the shortness of life instead of the improving his character. The number of years of human life appears not to be important for Stoics. They condemn an aim for long life, if it not connected with an aspiration for wisdom. 
